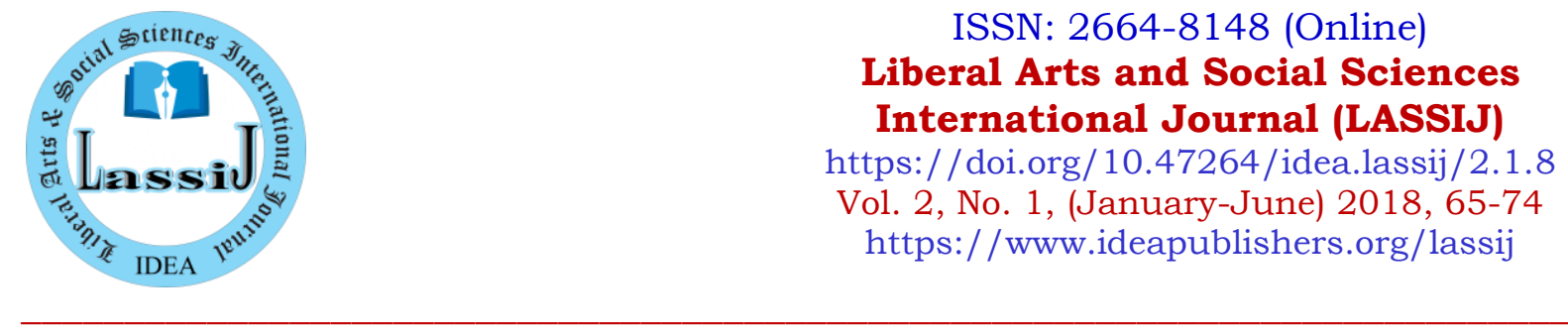

\title{
A Historical Perspective of China's Peaceful Policies and its Rise as World Economic Power
}

\author{
Aasia Khatoon ${ }^{1}$, Nazim Rahim ${ }^{2 *}$ and Barkat Ali $^{2}$ \\ 1. Department of International Relations, National University of Modern Languages \\ (NUML), Islamabad, Pakistan. \\ 2. Department of Political Science and International Relations, Qurtuba University of \\ Science and Information Technology, Peshawar, Pakistan.
}

\begin{abstract}
China's rise as an economic power on the canvas of world politics is immensely being discussed by scholars and experts around the globe whether it will create a chaotic situation or it will be peaceful for global peace and security. The descriptive-analytical approach is used to investigate that how at present the history of China plays a significant role in development and promotion of its passive and non-violent image. Liberal Institutionalism has been applied for the data analysis and further explaining the situation. This study focuses on historical peaceful and accommodating political character of China while interacting with its neighbouring states. The same is going to happen in the scenario of current rise of China and especially its mega project of "Belt and Road initiative." While studying the political and military nature of historical China, we can easily assess that China is ready for collaborating and cooperating not only with its neighbouring countries but also seems serious to bring the other countries in the nexus. China is very well aware of the suspicion, misconception, fear and threat that prevails in the regional states viz-a-viz the status quo world powers that powerful China could create threats for their security and survival.
\end{abstract}

Keywords: History of China, Peaceful Rise, Economic Power, Belt \& Road Initiative

\section{Introduction}

China's entire dynastic period is fraught with civil-wars, economic and technological backwardness, and poverty. But, due to global trade connectivity through 'Old Silk Route' it was counted as one of powerful countries of Asia. Even having enough power, it never appeared as an aggressive and expansionist country for its neighbours. Against foreign colonial powers namely Spain, Holland, Portugal, Britain, France, and Russia, it fought wars only in its self-defence. It endured great disrespect and humiliation by subjugates which realised it the worth of peace, prosperity, unity, self-respect, and development. Considering this realisation, it has formed its future policies towards peace and development. The role of its past is still actively working in setting its current policy plans and ambitions. It secured credit of long struggle and great scarifies for establishing democratic form of government with technological development, social harmony, and justice. To keep intact these achievements, China sets its 
future policies focused on getting the economic growth, industrialisation and development. The world seems astonished by experiencing the speed of Chinese economic development and getting its maximum share in international trade.

Belt and Road Initiative (BRI) is renovation of Old Maritime Silk Route which was firstly developed by the rulers of Han dynasty (206BC - 220CE). BRI is a global economic interconnectivity project that has the potential to connect more than sixty countries and twothird world population of different continents. China would spend estimated 1.2 to 1.3 trillion dollars on further development of this initiative till 2027. The initiative is increasing its trade and political influence along with promoting mutual peace and development to other countries. China as a rising economic power is facing confrontation from global and regional powers which includes US, India, Japan, South Korea etc. Its sea-power politics by building seaports and naval-bases is important that very soon will bring major change in the world power politics. It is significantly developing its economy, military, and naval capabilities. Here, it is essential to study the direction of Beijing's policies whether its active role builds its peaceful image or not. In this study China's historical behaviour will be explored and its current attitude will be analysed in the light of historical data. Currently, the present scenario of the world undergoes a dynamic change towards economic and trade development in which China is playing a leading role.

\section{Background}

China has approximately 5000 years old civilisation that has been developed by annexation of diverse cultures. It has been ruled by various dynasties for centuries including Xia dynasty, Shang dynasty, Zhou dynasty, Chin dynasty, Han dynasty, Sui dynasty, Tang dynasty, Later Liang dynasty, Song dynasty, Da Yaun or Mongol Dynasty, Ming dynasty and Qing dynasty. These different dynasties were originally representing different nations and civilisations certainly belonged to pure Chinese nation. Its own civilisation remained superior over all other civilisations that migrants brought with themselves. This civilisation got merged with migrated nationalities, cultures, and identities. Entire dynastic period was filled with continuous conflicts and civil wars that kept different tribes persistently in power struggle. Militarily strong tribes ruled over the weak tribes (Bo, 2008: 13-46; Murphey, 2006:141-160). While for outside world, it remained peaceful as first, the internal wars did not allow it to expand its territory. Second, being an empire, it had a power to occupy its surrounding small and weak neighbouring countries, but it always shown good gestures towards its neighbours. Third, the study of its history and civilisation shows she never remained an expansionist and aggressive nation. In addition, its history shows, 'Chinese nation did practice peaceful teachings of its civilisation and they looks their civilisation with great respect as three core teachings of their civilization which are peace, unity and development are incorporated in its national policy central objectives (C.Y.HSU, 1970: 19-317).

Moreover, being a non-expansionist and non-aggressive country in past, during entire dynastic rule, for trade revenues China remained dependent on agricultural sector, seaports, sea-lanes, and natural resources. It was famous by the production of agriculture products, cotton, tea, silk etc., and was independent in generating and fulfilling the economic needs of its people. It had many Seaports (like, Guangzhou, Quanzhou, Shanghai etc.) in its eastern part through which it developed economic interconnectivity with other countries of the world. It was taking high revenue from the Asian countries on use of Sea-lanes of South-China Sea. On these bases, it was counted as one of the strong and powerful countries in Asia and West. She left West behind 
in technology by making new inventions in agricultural and technological fields that were never made before by any other country in West. It invented the printing-machine, paper-making technology, gunpowder, medicine (herbs medicine), cultural-art, handicraft products etc. These developments were more explored by the West as they had an advanced scientific technology that China lacked (Bo, 2008: 13-46; Murphey, 2006: 141-160). History reveals the facts that from thirteenth to nineteenth century, China remained backward, deprived in technological and industrial development as it was subjugated by "Mongols", and later by other foreign powers (Murphey, 2006: 155-157).

China, despite having foreign occupiers' pressure, did not follow interests and policies that are based on the policy of expansionism. In $15^{\text {th }}, 16^{\text {th }}, 17^{\text {th }}$ and $18^{\text {th }}$ Century, it had borne a severe threat to its sovereignty from the imperial powers of Portugal, Spain, Dutch, Britain, France, Russia etc. These powers tried to occupy China's vast territory, seaports and natural resources that included stains, silk, chinaware, pearls, spices, ginger, incense, goldthread etc. However, these powers remained fail to establish their colonial regimes in China for a long time. To stop these colonial powers, China used the non-violent methods by reducing economic privileges, building walls to prevent their forward marching, and banning the diplomatic relations. But in response, it did not conduct a war or a violent attack on these occupation forces to defend its sovereignty. China fought wars just to protect its sovereignty whenever she faced an attack by any aggressive state.

In 1839, the Great Britain declared first "Opium War" on China when it had stopped secret exporting of opium stock by a Chinese merchant to European countries. In 1858 as in second Opium War, the Great Britain and France jointly attacked on China. Guangzhou and Tianjin Seaports were occupied. In 1860, the treaty of Tianjin was signed to end this war. China violated the treaty of Tianjin treaty by imposing restrictions again on opium sale. In response, the Great Britain and France again attacked on China. These entered Beijing and burned the China's summer palace ${ }^{1}$ and destructed other places. Similarly, in 1884, Japan declared war on China but remained fail to conquer it completely. China lost its control on Taiwan and Korea. The war was ended after eleven years in 1895 after signing the treaty of Shimonoseki. Japan attacked on China in 1895, 1905 and then in 1939. In 1939 war, Japan fully occupied China and it fought a guerrilla war to pull-out the Japanese forces from its land (Bo, 2008: 24-47; Murphey, 2006: 388-477).

China learned from these past experiences the significance of technology, economic development, and modernisation. It realised that technological backwardness was the main reason due to which it had suffered many regrettable pains of such wars. Later, in result of this learning, it launched "Self-strengthening Movement" to combat all those issues and challenges that were responsible for weakening its sovereignty particularly inter-state civil wars and rebellion movements etc. Chinese people considered the civil war as a main hurdle in a way towards advancement and development as it was deprived from these two. These weaknesses allowed Britain and Japan to occupy the Chinese territory. Under this Movement, 'she introduced reforms to reduce its backwardness and poverty.' Moreover, it declared necessary for its nation to learn the western language as priority to understand its (western) education and methods to facilitate their own struggle to attain a political and social development and advanced technology.

After the "Self-strengthening Movement," consecutively China launched a "Grand National Movement" to achieve change, development, and power. Moreover, they realized soon that 
dynastic rule as a governing system would be no longer an appropriate and ideal to deal with socio-political challenges and issues particularly poverty and backwardness. In 1911, first China's political party Kuomintang or Nationalist Party led by Sun Yat-Sen ${ }^{2}$ (1866-1925) brought a great revolution to erode the dynastic rule of the Qing Dynasty. The blood revolution took place successfully. At first, the care-taker democratic political government was established which was headed by Yuan Shikai who previously worked as a military personal in Qing Dynasty (Bo, 2008: 13-46; Murphey, 2006: 141-249). In 1913, the first General Elections were held which was the first step towards the establishment of first democratic political system in the country. Kuomintang or Nationalist party won the elections with majority votes and being declared eligible to establish their government. But care-taker President Yuan Shikai refused to leave the Presidency. Already frustrated Chinese nation launched rebellion movements for his removal. For the next twelve years, Chinese people remained in civil war.

The year 1915 proved very risky for Yuan Shikai when he secretly accepted twenty-one demands of Japan as it was perceived as an unbearable enemy by Chinese nation. This deal gave a remarkable boost to already on-going revolution. The students, businessmen, local and even jobless communities, political parties, and ethnic groups came out on roads in demonstrations. They demanded for the abolition of Sino-Japan secret agreement, establish democracy in political and social system, removal of old, shabby and tyranny traditional system of feudalism and agriculture that gave a subjugated and discriminatory life to Chinese nation. On May $4^{\text {th }}, 1919$, the protestors' demonstrations known as "May Fourth Movement" were badly erupted all over the country (Murphey, 2006: 330-341). Mao was leading that movement. He changed the minds of people by delivering thought-provoking and courageous speeches and gave a new life to revolution. He quickly became a popular figure because of positive nationalist idiosyncratic traits. His speeches were courageous and bold as it charged the demonstrators. He encouraged common people particularly the conservative class to follow West for the development they had made. He started a campaign from a grass-route level to encourage Chinese nation for a revolutionary change (Grenville, 1997: 417-423; Murphey, 2006: 330-341).

He delivered spiritual, emotional, and thought-provoking speeches and gathered people on one platform. In 1921, he established China's Communist Party (CCP). In 1939, Sino-Japan War, many Mao's supporters resisted and defeated Japan by playing guerrilla war tactics. Until 1940, Mao got a support of vast number of poor masses and all other classes of the society. It was a great up rise of peasants in China's history. They also got momentum and support by the revolutionary factors in Russia. Mao established a Red Army that consisted of his supporters to fight for their political objectives. In 1945, the number of the Communist Party supporters reached to 100 million. The Communist Party replaced Kuomintang (the Nationalist Party) by gaining more popularity and influence among the people on basis of transferring values of nationalism, unity, power, prudent ideology, and motivation for blood's sacrifices. In 1949, Communist Party succeeded in bringing communist revolution by defeating Chinese nationalist General Chiang Kai Shek of Kuomintang. Mao declared China an independent country with new name of People's Republic of China. Mao came into power as first President of China (Grenville, 1997: 417-419).

The existing literature is related to the dynamics of China's historical development that gives boost to its current economic, political, and strategic goals. By showing its peaceful and accommodating history China insists on its peaceful rise. The literature ignores the China's 
history to describe and analyse in peaceful perspective, that are the bases of its today policy particularly its policy on Belt and Road initiative that promotes mutual peace, cooperation, interdependence and integration.

\section{Methods and Material}

In this paper, descriptive-analytical approach is used to analyse the struggle and sacrifices of Chinese nation throughout its history. The study aims to explain how an assessment of its past policies is crucial and how that is setting up its current policies and her image particularly under the Belt and Road Initiative for peaceful rise as world economic power. Most of the data collected for this study is taken from secondary sources especially the first portion of China's history with perspective to its global economic rise and peaceful image of growing world power. The primary data is also consulted when the researchers have talked about the current BRI project of China. Speeches and statements of Chinese and Pakistani officials have remained a special focus during this work. Apart from this; books, newspapers, journals, electronic sources, government publications, organisational reports, and interviews were also consulted to analyse the situation accurately.

\section{Post 1949 Era: Struggle for Political, Economic, and Social Security}

After independence, being as newly born inexperienced un-democratic country, China considered it better to follow Marxist communist ideology which was already prevailing in its neighbouring country Soviet-Union. It idealised and preferred Communism over Capitalism as it viewed this ideology would remove all social and economic inequalities that resultantly make the Chinese society prosper and peaceful. But its likeness towards communism had provided many security challenges to it. Western capitalist countries posed various security, economic and political challenges for China to punish it for being a communist country and for keeping an alliance with the Soviet-Union. ${ }^{3}$ To engage China in restlessness at Taiwan, US provided military, political and economic support to the self-exiled Nationalist leader Mr. Chiang Kai Shek of Kuomintang ${ }^{4}$ to intensify security situation and a security challenge for Beijing. Though having all sorts of challenges, China always followed the defensive measures to ensure its safety. China in a hidden way supported the Communist Political Party of Kim-II Sung in North Korea to overcome the influence of the capitalist political party which was secretly supported by US and Japan.

The main reason behind this hidden support was to protect its sovereignty in future as its borders were adjacent to North-Korea. In response, US provoked a civil war in Taiwan by providing military aid to the Nationalist Political Party to annoy it (China) and to stop it from supporting communist party in North-Korea. US succeeded in its attempt as according to its own intelligence reports, in June 1950 when issue of Korea got impetus, China did not provide military and economic assistance to North-Korea. But, at UN platform, it vetoed all the resolutions presented by the US against the North-Korea. It intervened into war to secure its borders when North-Korea lost its power to resist more and US-NATO and South-Korean military forces crossed the 38-Parallel Line ${ }^{5}$ and entered in North-Korea. It pushed back the military forces of adversaries and occupied Seoul (Capital of South-Korea) with significant help of the former Soviet-Union that provided it support of tanks, troops, and weapons. Resultantly, US imposed sanctions over Beijing for its participation in the conflict against US (Murphey, 2006:388-417). Moreover, it did support communist governments in Thailand, Cambodia, and Burma particularly to defend its border, security, and sovereignty. In 1964, it 
successfully eroded the US supported capitalist government in Thailand (MacFarquhar \& Fairbank, 1987: 529-538).

During the Cold War, besides security challenges, China was striving with various domestic social issues like poverty, backwardness, unemployment, imbalanced education level, illiteracy, lack of technological awareness etc. The then existed class-gap was considered the main reason for these all problems. To curb these issues, China's Communist Party (CPC) launched a "Great Leap Forward' movement in 1958 (Bo, 2008: 13-47); the private ownership of the people over homes, business, wealth and property was removed. About fifty large Joint Communities were established, as each community contained with 20,000 thousand families. The people were jointly living in large halls and were using the same halls for eating. They all were used to wear same blue or grey uniform. Moreover, five-year plans were initiated twice for development. Always, an unprecedented and unrealistic target were set which were beyond realities. The first five-year plan was made in 1957 in which 50 to 60 million tons of steel production was planned to be made by 1962 . To attain this goal, the entire Chinese nation started the production of steel and Iron. In agriculture sector, the production of grain was being targeted to gain an increase. In 1958, another five-year plan was proposed mainly to increase the grain production from 250 to 350 billion $\mathrm{kg}$. In the beginning, the production speed remained much high.

In 1959-60, India provided hidden military support to Tibet militants to provoke their resistance against China. In response, China rather than taking a military action preferred to resolve issue through negotiations. India did not agree on any settlement. This issue became a great challenge for China's security as it was already passing through a problem of economic and technological backwardness. To overcome this threat, its Prime-Minister Chou-Enlai paid visit to India for six days to normalise its relations (MacFarquhar \& Fairbank, 1987: 509-513; Bhattarai, 2010). In 1960, after President Stalin's death in former USSR, the newly elected President Khrushchev opposed radical policies of Mao with a fear that these policies could bring a revolutionary change in the Soviet-Union. To stop this effect, former Soviet-Union broke all economic, technological, and military assistance agreements with China. That Sino-Soviet split was a great set-back for a weak country like China which was heavily relying on Soviet-Union for economic assistance almost in all sectors (Cheng, 2010; Tauris, 2010). For next twelve years, China followed the policy of "self-reliance or Autarky" and "non-align policy" to oppose the imperialist, suppressive and aggressive plans of both superpowers. China realised that both US and Soviet-Union have obstructed its economic development and based on the ideological differences, they are posing security threat to its security, integrity and sovereignty (Sutter, 1978; Kleinberg, 1990: 105-107).

China's policy priorities were completely changed and became completely focused on trade, economic development, technological advancement and industrialisation. To pull-out the African countries from Soviet-US influential circle, it established Afro-Asian People's Solidarity Organization (AAPSO) and provided heavy funding and other support to these countries. In same policy wave, it tried to strengthen economic, military, and diplomatic relations with Western capitalist block (MacFarquhar \& Fairbank, 1987: 529-538). In 1978, China's Prime Minister Deng Xiaoping launched the reform policy for economic, technological, and political development by opening its economy for the outside world. It enhanced diplomatic relations even with countries that shared worse history of subjugation as in same year (1978) by signing "Treaty of Peace and Friendship" with Japan. It decided to maintain peace and development in its relations with other countries to expand and attain trade 
and technological advancement (Kornberg \& Faust, 2007: 136-141). In 1979, China normalised relations with US by establishing official diplomatic relations. (MacFarquhar \& Fairbank, 1987: 529-538). In same year, China purchased arms from US to ensure security from Soviet-Union at Afghanistan side.

In 1982, its relations with US disrupted due to its (US) hidden arms supply to Taiwan. To get security support and to sustain US pressure, she normalised its relations with the Soviet-Union. Further throughout 1980s, it followed an independent foreign policy by not tilting towards any of these superpowers (Idrees, Naazer, \& Rehman, 2017). After 1988, to reduce US imperialism and to increase its frustration, China provided nuclear technology and equipment to Iran and other countries of the Middle East (Dreyer, 1989: 91-96). Resultantly, in 1999 US and NATO (North Atlantic Treaty Organization) bombed China's embassy in Belgrade. That incident pushed Chinese nation to appear more united, strengthened, and loyal to its government than ever before. The thousands of Chinese protesters crushed US embassy in China and imprisoned US Ambassador and other diplomats. China's President rejected intense condolences and regrets that made by US President Mr. Bill Clinton. Beijing strongly retaliated to this attack by saying historical words in an article entitled "This is not 1899 China" published in people's daily newspaper that this is not the time when China was victimised by Western imperialism that had demolished old summer palace, seized Hong Kong and Macao. Now, this is a new China that stood up on its own feet, it is a China that defeated Japanese fascists; it is China that got victory over US in Korean battlefield. The sovereignty, dignity of Chinese people cannot be violated. Chinese have a hot blood as since last 150 years they are opposing imperialism. US led NATO can better understand this. The protest made China and US relations bitter, but both did not break diplomatic and trade relations (Gries, 2004: 30-224; Saeed, 2011).

During Cold War, China got a bitter experience of threats of challenges of hegemony, powerinfluence, discrimination, aggression and imperialism that realised it the worth of economic, industrial and technological development for protection of sovereignty, independence and freedom. Considering that realisation, she initiated various economic development programs such as 1950 s political and social reforms policy programs, 1960's Five-years development plans, 1978 opening-up policy, 'China's Dream Policy' to build China as industrialised and modernised country till 2050 (World Bank Report, 2013; China Daily, 2013, December) and a plan of peaceful harmonious society till 2030 to combat economic and social challenges in trade, environment, education, health, fiscal sectors (World Bank Report, 2013; Malik, \& Schultz, 2008). Being part of Dream Policy in 2013, China launched global economic interconnectivity project of BRI to secure economic development and energy interests (Ministry of Foreign Affairs China, 2015). The basic purpose of these all development projects to provide more job opportunities, to raise living standard and middle-income of its individuals and to reduce ethnic security challenges and poverty. China as a developing country has set up priorities for its progress and to maintain her own social peace and prosperity first (Ministry of Foreign Affairs China, 2015; World Bank Report, 2013; China Daily, 2013, December).

The US, Japan, and India assume China's rise especially its BRI project as a threat to their interests (Mohan, 2014; Yee, 2011; Muzaffar, Yaseen, \& Rahim, 2017). Beijing is renouncing the claims on its peaceful rise by saying that it is placing the initiative on the bases of five principles of peaceful coexistence which are cooperation, benefits, non-interference, respect to each other sovereignty, and territorial integrity. Under this initiative, it is following a noninterference policy (China Daily Europe, 2015, March). These principles are given by the great leaders Mao Zedong and Deng Xiaoping which are still followed by the current leadership as 
a compulsion in the context with a great honour. Their inheritors continued the policy pf resentment the words 'hegemonic power" and "super-power" (China Daily, 2013, December). About its peaceful rise, Xi Jinping has also said, "No matter how much stronger it may become, China will never seek hegemony or expansion. It will never inflict its past sufferings on any other nation" (China Daily, 2015, September).

This initiative secures trust of countries by connecting Asia, the Central-Asia, Europe, Middle East and Africa to promote common trade for mutual benefit (China Daily Europe, 2015, March). Nonetheless, China through this initiative is building trade partnerships with other countries but not establishing military alliances and military bases. It is not seeking hegemony or a status of global military aggressive power as it has no military alliance (Jianmin, 2015; Mackerras, 2001). Hu Shi Sheng said, "Through globalisation and communication, how China can be worse" (Sheng, 2014, May). This initiative provides equal economic and social benefits to all participant countries. It is reducing North-South gap by transferring technological and financial support to developing countries for building infrastructure, energy projects, roads, railway links, and economic zones etc., (Ministry of Foreign Affairs China, 2015). It is shifting the existing world political order of hegemony and power-influence with new world order of Chinese characteristics of mutual peace, cooperation, interdependence, and integration (Liu, 2015). Pakistan's ex-Ambassador to China Mr. Akram Zaki has once stated on peaceful rise of China "Han dynasty, Song Dynasty and Tang dynasty were glorious periods. Although, China wants to revive the old glory, however, she is peaceful, and want to develop peaceful relationship with other countries of the world (Zaki, 2015, August).

\section{Conclusion}

China's history provides it worth of peace, prosperity, and development. Past experiences of wars, humiliation, hardships, and sacrifices plays crucial role by lying basis of China's foreign policy about Belt and Road Initiative on non-interference, anti-imperialism, and antihegemony. The current circumstances prove China's rise as a global economic power particularly though Belt and Road initiative is peaceful. The initiative is increasing economic and political influence of China, but it is not seeking hegemony as it is equally promoting development and prosperity to other countries. Additionally, it is not making military alliances and bases. It will never go for a war at the cost of its heavy capital and investment for BRI, on initiative and at cost of its own people welfare and development for which they gave bloody sacrifices. Under the initiative the security and loss of one country is now interlinked with security and loss of other country.

\section{References}

Bo, J. (2008). Understanding China: Introduction to China's History, Society and Culture. Beijing: China Intercontinental Press.

Bhattarai, K. P. (2010). Rising India and China: Can two Tigers Learn to Share a Mountain. Retrieved from: http://www.eurasiareview.com/05092012-rising-india-and-chinacan-two-tigers-learn-to-share-a-mountain-analysis/

C.Y.HSU, I. (1970). The Rise of Modern China. New York: Oxford University Press.

Cheng, D. (2010, August 31). China's View of South-Asia and the Indian Ocean. Retrieved from: http://thf_media.s3.amazonaws.com/2010/pdf/hl1163.pdf 
China Daily. (2013, December 8). Making Chinese dream a reality. Retrieved from: http://www.chinadaily.com.cn/china/Chinese-dream.html

China Daily. (2015, September 3). China to Cut Troops by 300,000: President Xi. Available at: http://www.chinadaily.com.cn/world/2015victoryanniv/201509/03/content_21782967.htm

China Daily Europe. (2015, March 30). Initiative Offers Road Map for Peace, and Prosperity. Retrieved from: http://europe.chinadaily.com.cn/china/201503/30/content_19950708.html

Dreyer, J. T. (1989). China's Political System. London: Macmillan.

Fox, M. S. (2003). China and South-East Asia: Tribute, Trade, and Influence. Australia: Allen \& Unwin.

Gries, P. H. (2004). China's New Nationalism: Pride, Politics and Diplomacy. United States: University of California press.

Grenville, J. A. S. (1997). A History of the World in the Twentieth Century. United-States: Professors World Peace Academy.

Idrees, M., Naazer, M. A., \& Rehman, A. U. (2017). Conflict and conflict management in SARRC. LASSIJ, 1(2), 1-11.

Jianmin, W. (2015 May 11). China Opposes Alliances with any other. Retrieved from: http://www.chinadaily.com.cn/opinion/2015-05/11/content_20677200.htm

Kleinberg, R. (1990). China's Opening to the Outside World: The Experiment with Foreign Capitalism. United States: West view Press.

Kornberg, J. F., \& Faust, J. R. (2007). China in World Politics: Policies, Processes, Prospects. USA: Lynne Rienner Publishers, Inc.

Liu, C. (2015, October 30). Belt and Road to Build New World Order. Available at China Daily: http://europe.chinadaily.com.cn/epaper/2015-10/30/content_22313280.htm

MacFarquhar R., \& Fairbank, J. K. (1987). The Cambridge History of China. New York: Cambridge University Press.

Mackerras, C. (2001). Contemporary China. New York: Cambridge University Press.

Ministry of foreign Affairs China. (2015, March 28). "Vision and Actions on Jointly Building Silk Road Economic Belt and $21^{\text {st }}$ Century Maritime Silk Road. Retrieved from: http://en.ndrc.gov.cn/newsrelease/201503/t20150330_669367.html

Mohan, C. R. (2014, June 11). Chinese take away: String of Pearls. Retrieved from Indian Express

Newspaper: http://indianexpress.com/article/opinion/columns/chinesetakeaway-string-of-pearls/

Murphey, R. (2006). A History of Asia. New York United States: Pearson Education, Inc.

Muzaffar, M., Yaseen, A., \& Rahim, N. (2017). Changing dynamics of global politics: Transition from Unipolar to Multipolar world. LASSIJ, 1(1), 49-61.

Malik, V. P., \& Schultz, J., (2008). The Rise of China: Perspectives from Asia and Europe. India: Pentagon press.

Saeed, A., (2011). China's quest for energy and diplomacy. Strategic Studies Journal, 31(3), 229-247.

Sheng, H. S. (2014, May). Interview of Dr. Hu She Sheng (PhD) with first author on $27^{\text {th }}$ May 2014.

Sutter, R. G. (1978). Chinese Foreign Policy after the Cultural Revolution: 1966-1977. United States: West View.

Tauris, I. B. (2010). China: A Modern History. New York: Michael Dillon.

World Bank Report. (2013). China 2030: Building a Modern, Harmonious and Creative Society. 
http://www.worldbank.org/content/dam/Worldbank/document/China-2030-

complete.pdf

Yee, H. S. (2011). China's Rise: Threat or Opportunity. London: Routledge.

Zaki, A. (2015, August). Ex-Ambassador to China Akram Zaki's interview with first author on August 20, 2015.

\section{Notes:}

1 The Summer-Palace in Beijing was the part of empirical garden that was built during the Qing Dynasty by emperor Qianglong in $17^{\text {th }}$ Century. It is consisted of traditional halls and pavilions. In 1840 and 1900, it was destroyed by invaders and in 1912, it was rebuilt by the government of Qing Dynasty. In 1924, it was opened for the tourists.

${ }^{2}$ He belonged to a Peasant family.

${ }^{3}$ China made alliance with Soviet-Union to remove its economic and technology backwardness.

${ }^{4}$ Nationalist Political party that earlier known as Kuomintang Political Party expelled by Mao and its supporters to Taiwan.

${ }^{5}$ Demarcated boundary line between South and North Korea. 